\title{
Bazı fiziko-kimyasal toprak özellikleri ile bazı erodibilite parametreleri arasındaki ilişkilerin mikro havza ölçeğinde değerlendirilmesi
}

\section{Assessment of the relationship between some physico-chemical properties of soil and some erodibility parameters in micro basin scale}

\author{
Fikret SAYGIN ${ }^{1}$ iD, Orhan DENGiz ${ }^{2}$ iD, Serkan iç ${ }^{1}$ id , Ali iMAMOĞLU ${ }^{3}$ iD \\ Isparta Uygulamalı Bilimler Üniversitesi Orman Fakültesi Orman Mühendisliği Bölümü, Isparta Türkiye
}

Eser Bilgisi/Article Info
Araştırma makalesi/Research article
DOI: $10.17474 /$ artvinofd.481642
Sorumlu yazar/Corresponding author
Orhan DENGiZ
e-mail: odengiz@omu.edu.tr
Geliş tarihi / Received
12.11.2018
Düzeltme tarihi/Received in revised form
30.03.2019
Elektronik erişim/ Online available
11.04.2019
Anahtar kelimeler:
Agregat stabilitesi
Dispersiyon oranı
Toprak fiziko-kimyasal özellikler
Keywords:
Aggregate stability
Dispersion ratio
Soil physico-chemical properties

\begin{abstract}
Özet
Dünya'nın birçok yerinde, verimli toprak katmanlarını taşıyıp, taşındığı yerde toprağın ekosistem içerisindeki fonksiyonel özelliğinin yitirmesinin yanı sıra, eğim doğrultusunda hareket ederek biriktiği yerde çevresel, ekonomik ve tarımsal yönden zarar oluşturan erozyon olayı önemli bir çevresel sorun oluşturmaktadır. Toprakların aşınmaya karşı göstermiş oldukları direnç ve strüktürel açıdan dayanıklılıkları, erozyona uğrama eğilimini göstermekte ve bu sebeple erozyonun yönü ve boyutu belirlenebilmektedir. Toprağın aşınabilirlik karakterlerinin belirlenmesi, erozyona uğrama eğiliminin tespit edilmesi açısından önemli bir yaklaşım olduğu söylenebilir. Bu çalışmanın amacı, Türkiye'nin Doğu Karadeniz Bölgesi'nde Rize ili sınırları içerisinde yer alan mikro havzaya ait çay tarımı yapılan toprakların bazı fiziko-kimyasal özellikler ile erozyona duyarlılık parametreleri olan dispersiyon oranı (DO) ve agregat stabilitesi (AS) arasındaki ilişkinin değerlendirilmesidir. Bu amaçla, mikro havza içerisinde çay tarımı yapılan arazilerden 28 farklı noktadan toprak örneği alınmışır. Laboratuvar analizlerinden sonra elde edilen veriler istatistiksel olarak test edilmiştir. Analiz sonuçlarına göre, mikro havza içerisinde çay tarımı yapılan tarım arazilerinden alınan toprakların erozyona karşı hassasiyetleri değişkenlik göstermektedir. Toprakların DO değerleri \%3.85 ile \%18.14 arasında değişirken, AS değerleri \%55.52 ile \%92.02 arasında değişim göstermiştir. AS, DO ve diğer toprak özellikleri ilişkisinde en yüksek pozitif korelasyon organik madde ile azot $\left(0.89^{* *}\right)$ görülürken, en yüksek negatif korelasyon kum ile silt $\left(-0.83^{* *}\right)$ arasında belirlenmiştir. Ayrıca yapılan korelasyon testinde DO ve AS arasında önemli düzeyde negatif ilişki olduğu bulunmuştur.
\end{abstract}

\begin{abstract}
In many parts of the world, soil erosion causes losing of soil functional features in ecosystem by carrying surface depth which is fertile layer and gives environmental, economic, and agricultural damages by means of transporting along with the slope due to accumulating process is one of the most environmental problems. Resistance of soils against to erosion in terms of their structural stability shows a tendency for vulnerability of erosion, thus, it is possible to determine the direction and size of the erosion. In addition, it can be said that determination of soil erodibility characteristics is an important approach to detect tendency of soil erosion. The aim of this study was to evaluate relationships between some erodibility factors (dispersion ratio (DR) and aggregate stability (AS)) and some physico-chemical properties of soils used for tea cultivation in micro basin located at Rize province at Eastern Black Sea Region of Turkey. For this purpose, 28 soil samples were taken from different location points of tea cultivated land in micro basin. After laboratory studies, the data obtained were tested statistically. According to the analysis, results show variability against erosion of the soils. It was found that DR values of soils changed between $3.85 \%$ and $18.14 \%$ while, AS values were determined between $55.52 \%$ and $92.02 \%$. Moreover, it was determined the highest positive correlation relationship between AS, DR and organic matter and nitrogen $\left(0.89^{* *}\right)$, whereas the highest negative correlation relationship was found between sand and silt $\left(-0.83^{* *}\right)$. Also, there was detected significantly negative relationship between DO and AS in the correlation test.
\end{abstract}

\section{GiRiş}

Yüzyıllardır barınmanın yanında giyinmeye, yeme ve içme gibi hizmetleri insanoğlunun kullanımına sunan toprak, en cefakâr dosttur. Toprağın bulunduğu yerden çeşitli kültürel uygulamalar ile aşınmaya ve taşınmaya uğraması yani erozyon ile tahribi de insanoğlunun dostuna karşı en acımasız tavrını sergilemektedir. Dolayısıyla erozyon, toprağın karasal ekosistem içerisinde yüzyıllar boyunca kazanmış olduğu fonksiyonunun, geri dönüşümü mümkün olmayacak şekilde kaybolmasına neden olan bir olaydır. Bu nedenle, yıllarca doğal etmenlerle bulunduğu yerde oluşum ve gelişim süreci içerisinde olan toprağın yapay olarak artışının sağlanamayacağı gibi, varlığını uzun 
yıllar sürdürebilmesi açısından, bulunduğu yerde korunumunun sağlanması gerekmektedir.

Çok önemli doğal varlıklar olan toprak ve su kaynaklarının etkin ve devamlılı̆ı sağlanarak kullanımının, gerek karasal ekosistemin devamlılı̆ı gerekse de gıda güvenliği açısından, nüfustaki hızlı artış göz önüne alındığında önemi daha da artmaktadır. Toprağın erozyona karşı hassaslığı, onun erozyona uğrama eğilimi ya da uygunluğu olarak tanımlanabilir. Su erozyonunda taşınan toprak miktarı yüzey akışın taşıma gücünün yanında, toprağın aşınabilirliğine de bağlıdır. Toprağın aşınabilirliği (erodibilite) ise; parçacıkların büyüklüğüne, şekline, yoğunluğuna, bitki örtüsü ve yüzey pürüzlülüğü gibi diğer faktörlerin geciktirme etkisine bağlıdır. Aynı yağış, farklı toprak çeşitlerinde farklı oranlarda parçalanma, aşınma ve taşınmalara sebep olabilmektedir (Aşkın ve ark. 2016). Ayrıca, iyi bir strüktürel gelişim, toprakta bitkinin kök gelişimine dolayısıyla verim ve kalitenin artmasına yardımcı olduğu gibi, toprağın özellikle parçalanmasına ve taşınmasına karşı dayanıkııı̆ını da artırmaktadır. Bryan (1976) agregatsal oluşumunda farklılığa neden olan etmenlerin, toprakların erozyona maruz kalma eğilimlerini önemli ölçüde etkilediğini belirlemiştir. Ayrıca, toprakların agregat büyüklük dağılımları ve stabilite ölçümleri, toprakların önemli kalite göstergeleri olarak kabul edilmektedir (Özdemir ve ark. 2015; Eraslan ve ark. 2016). Bununla birlikte, agregat stabilitesi toprak agregatlarının bozulmayı oluşturan çevresel etmenlere karşı içsel direncinin belirlenmesinde önemli bir parametre olarak kullanılmaktadır. Bu nedenle, agregat stabilitesi değeri toprağın erozyona karşı eğilimini göstermesinde önemli bir faktör olarak değerlendirilir. Bu anlamda, Yakupoğlu ve ark. (2016) agregat stabilitesi değerinin artması ile erozyona karşı dayanıklılığın artmakta olduğunu belirmişlerdir. Dispersiyon oranı ise toprakların suda dağılmaya karşı dirençlerinin bir göstergesidir ve aşınabilirlik parametresi olarak değerlendirilmektedir (Baumgartl 2002).

Türkiye, ekolojik değişkenlik yönünden özellikle de iklim ve topoğrafik koşullara sahip olması ve arazi baskıları nedeniyle, erozyonun meydana gelmesi için uygun şartları oluşturmaktadır (Kanar ve Dengiz 2015). Ülke alanının \%46'sı, \%40'tan fazla eğime, \%62.5'den fazlası da \%15'ten büyük eğime sahiptir. Arazi kullanım ve arazi örtüsü bakımından ise Türkiye' de özellikle işlemeli tarım alanlarının \%59'u, orman alanlarının \%54'ü, mera alanlarının \%64'ünde aktif erozyon bulunmaktadır (Anonim 2013). Bazı bölgelerin bitki örtüsünden yoksun olması rüzgâr erozyonunu tetiklerken, bazı bölgeler ise topografya ve iklim etkisiyle su erozyonunun etkisi altında kalmaktadır. Özellikle, Doğu Karadeniz Bölgesinde sarp ve dik yamaçlarda yanlış arazi kullanımı ile toprak direnci kırılmaktadır. Aşırı ve fırtınalı yağışların yanı sıra koruyuculuğu altında bitki örtüsündeki tahribat, direnci kırılan toprağı erozyona maruz bırakabilmektedir.

Doğu Karadeniz bölgesinde özellikle Rize ilinde çay tarımı yapılan alanların eğim değerleri oldukça yüksek olup bu alanların bitki örtüsünün koruyucu etkisi altında olmadıkları taktirde, gerek yağış gerekse de topografik özellikten dolayı kolay bir şekilde erozyona uğrama riski altında bulunmaktadırlar. Bu çalışmanın amacı Türkiye'nin Doğu Karadeniz Bölgesinde Rize il sınırları içerisinde yer alan mikro havzaya ait çay tarımı yapılan alanlarda yayılım gösteren toprakların bazı fiziko-kimyasal özellikleri ile erozyon duyarlılık parametreleri olan dispersiyon oranı (DO) ve agregat stabilitesi (AS) arasındaki ilişkinin değerlendirilmesidir.

\section{MATERYAL ve YÖNTEM}

\section{Araştırma Alanının Genel Tanımı}

Rize ili $40^{\circ} 21^{\prime}$ ve $41^{\circ} 25^{\prime}$ Doğu boylamları, $40^{\circ} 33^{\prime}$ ile $41^{\circ} 20^{\prime}$ kuzey enlemleri arasında yer alır (Şekil 1). Yüzölçümü 3920 km² olup, büyük bir bölümü dağlıktır (Anonim 2018a). Rize ili batıda Trabzon, güneyde Erzurum ve Bayburt, doğuda Artvin illeri ve kuzeyde ise Karadeniz yer almaktadır.

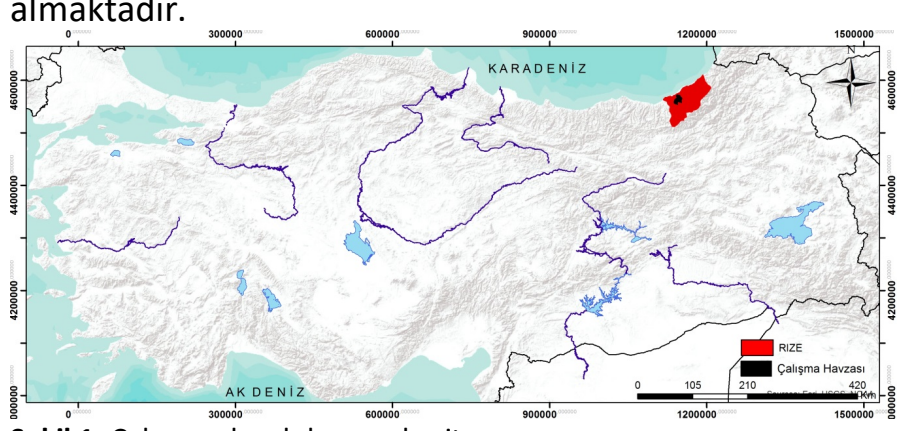

Şekil 1. Çalışma alanı lokasyon haritası. 
Çalışma alanı Rize il sınırları içerisinde yer almakta olup yaklaşık $172.3 \mathrm{~km}^{2}$ dir. Havzanın deniz seviyesinden yüksekliği $70 \mathrm{~m}$ ile $1972 \mathrm{~m}$ arasında değişmektedir.
Çalışma alanı düz, tepe, dalgalı gibi çok çeşitli topografik özelliklere sahiptir. Çalışma alanına ait yükseklik ve kabartı haritası Şekil 2' de gösterilmiştir.

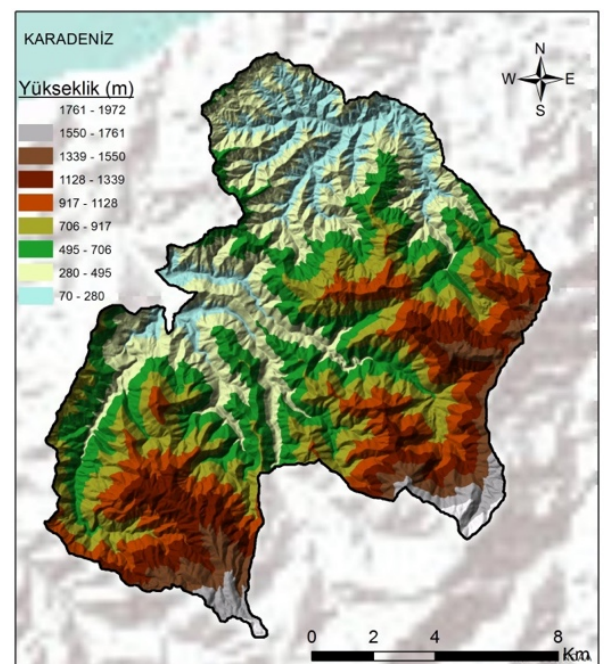

Şekil 2. Çalışma alanına ait yükseklik ve kabartı haritası

Toplam alanın büyük bir çoğunluğu \%15'ten fazla eğime sahiptir. Bunun yanında toplam alanın yalnızca \%2.5'i ise eğim olarak \%15'ten küçüktür. Ayrıca bakı haritasına göre

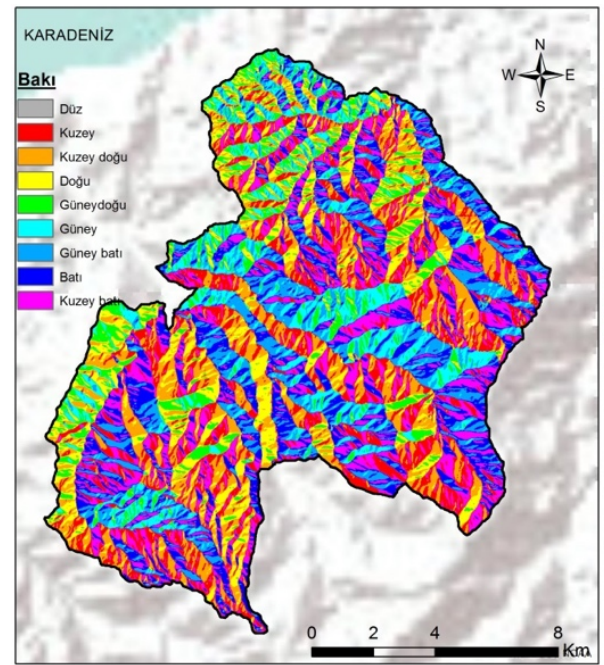

Şekil 3. Çalışma alanı eğim ve bakı haritası

Havzanın jeolojik özelliğine bakıldı̆̆ında büyük bir çoğunluğu andezit, bazalt, aglomera gibi magmatik kayaçlardan oluşan proklastik kayaçlar oluşturmasının yanı sıra yine asit magmatik kayaçlardan granit ve riyolitçe yaygın ana materyallerin olduğu görülmektedir. Ayrıca alanın kuzey batı kesimlerinde volkanik çökel kayalarda dağılım göstermektedir (Şekil 4) (Güven, 1993). çalışma alanı genellikle güney, güneydoğu-güneybatı ve kuzey, kuzeydoğu-kuzeybatı yönlüdür. Çalışma alanına ait eğim ve bakı haritası Şekil 3'te verilmiştir.
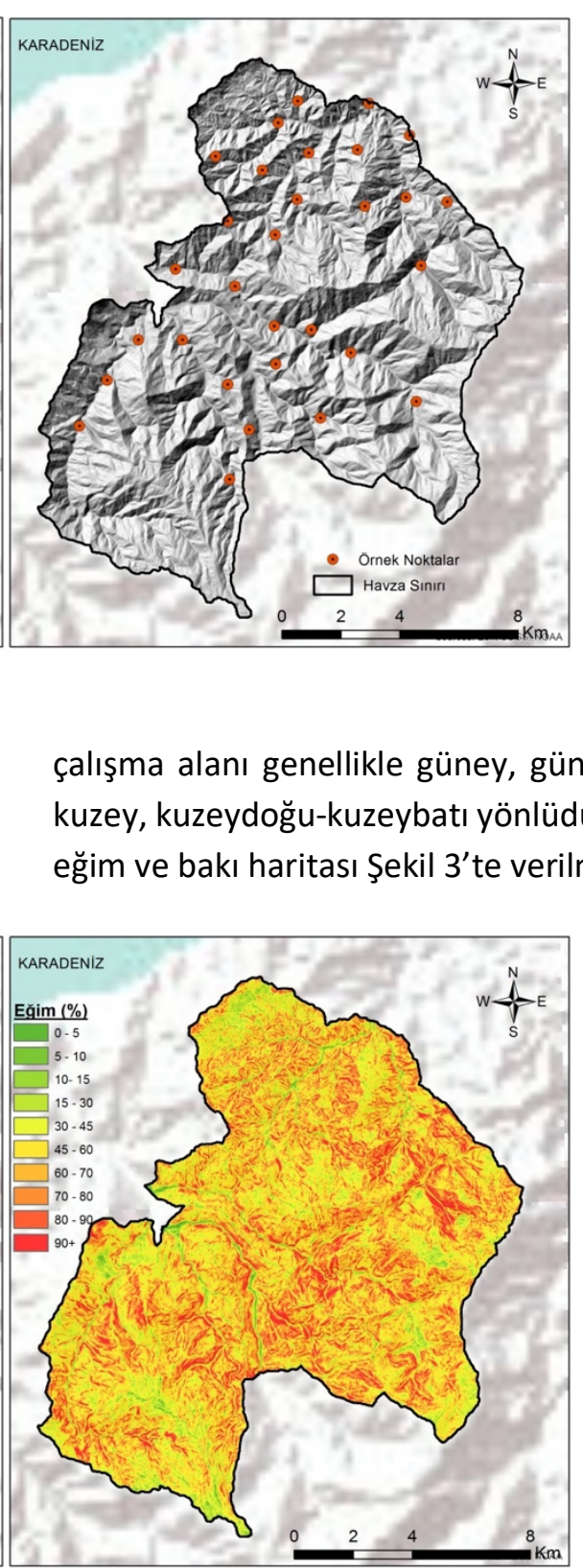

Rize ilinde Karadeniz iklimi hakimdir. Bu iklimin genel özelliği, yazları serin kışları ılıman ve hemen hemen her mevsim yağışlı olmasıdır. Bunda en büyük etken ise dağların kıyıya paralel uzanmasıdır. Uzun yıllar meteorolojik verilere göre, Rize'nin yıllık ortalama sıcaklığı $14.3^{\circ} \mathrm{C}$ olup, en düşük sıcaklık $6.5^{\circ} \mathrm{C}$, en yüksek sıcaklık ise $23.1{ }^{\circ} \mathrm{C}$ olarak tespit edilmiştir. En soğuk ay Ocak, en sıcak ay Ağustos'tur. Yıllık yağış miktarı yaklaşık 2300 mm' nin üzerinde olan Rize, Türkiye'nin en çok yağış 
alan ilidir. Rize'de yağış her mevsime dengeli olarak dağılmakta olup, kurak mevsimi yoktur. ilde en az yağış ilkbaharda, en çok yağış sonbaharda görülür. Nem oranı her zaman \%75'in üzerindedir (Anonim 2018b). Newhall simülasyon modeline göre (Newhall 1972; Van Wambeke 2000), $100 \mathrm{~cm}$ toprak derinliği için toprak sıcaklık rejimi Mesic, toprak su bütçesine göre toprak nem rejimi ise Perudic olarak belirlenmiştir (Şekil 5).

Şekil 4. Çalışma alanı jeoloji haritası
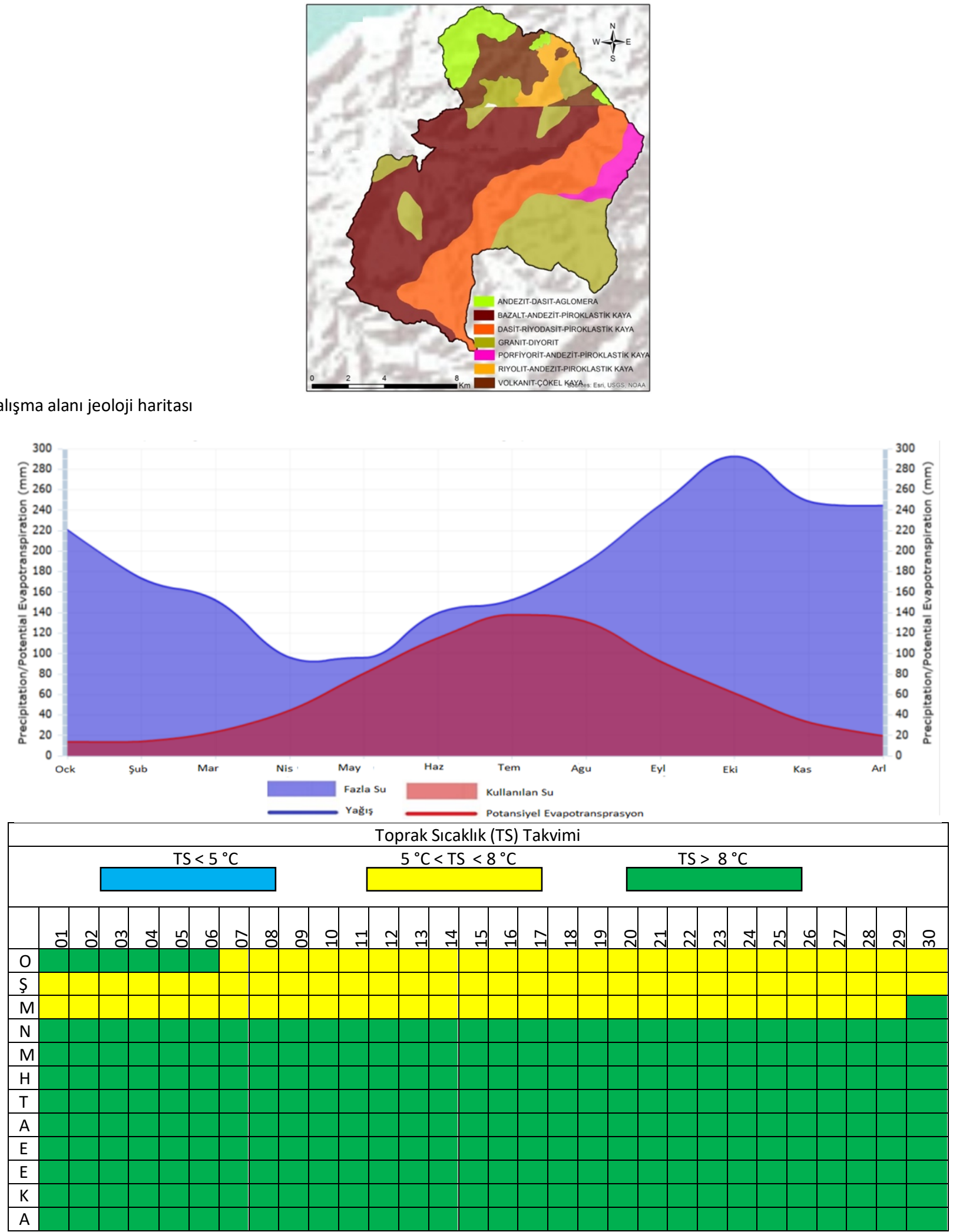

Şekil 5. Çalışma alanına ait Newhall modeline göre toprak nem ve sıcaklık rejimine ait diyagramlar 


\section{Yöntem}

Çalışma alanı olarak seçilen mikro havzada dağılım gösteren çay bahçelerinde mümkün olduğunca havzayı temsil edecek şekilde 28 adet çay bahçesinden toprak örneklemesi yapılmıştır. Çalışma alanından alınan yüzey toprak $(0-20 \mathrm{~cm})$ örneklerinde fiziksel ve kimyasal analizlerin yanı sıra, erozyon duyarlılık parametresi olan agregat stabilitesi ve dispersiyon oranı incelenmiştir. Bu amaçla; Dispersiyon Oranı (DO): Süspansiyonda dispers edilmeden ölçülen silt+kil \% değerinin, mekanik analizde ölçülen silt+kil \% değerine oranlanmasıyla hesaplanmıştır (Lal 1988). Agregat Stabilitesi (AS): Islak eleme metoduna göre, Yoder tipi eleme setinde ölçülmüştür (Kemper ve Rosenau, 1986). Toprakların tekstür sınıfları hidrometre yöntemi kullanılarak belirlenmiştir (Bouyoucous 1951). Toprak organik maddesi Walkley-Black yöntemiyle organik maddenin $1 \mathrm{~N} \mathrm{~K}_{2} \mathrm{Cr}_{2} \mathrm{O}_{7}$ ve $\mathrm{H}_{2} \mathrm{SO}_{4}$ ile oksitlenmesi ve $0.5 \mathrm{~N} \mathrm{FeSO}_{4} .7 \mathrm{H}_{2} \mathrm{O}$ ile geri titre edilmesi ile belirlenmiş ve \% olarak ifade edilmiştir (Kacar 1994). Toplam azot Kjeldahl yöntemi ile belirlenmiştir (Bremner 1965). Toprakların pH değerleri, 1:1 oranında hazırlanan toprak-su süspansiyonunda cam elektrotlu pH metre ile ölçülmüştür (Soil Survey Laboratory 1992). Toprakların elektriksel iletkenlik değerleri, 1:1 oranında hazırlanan toprak-su süspansiyonunda elektriksel kondaktivite aleti ile belirlenmiştir (Richards 1954). Toprakların toplam kireç miktarı, Scheibler Kalsimetresi ile tayin edilip \% olarak ifade edilmiştir (Kacar 1994). Değişebilir katyonların belirlenmesi amonyum asetat $\left(\mathrm{CH}_{3} \mathrm{COONH}_{4}\right)$ ile ekstrakt yöntemi ile (Sağlam 1997) ve toprak örneklerinde fosfor ise Bray ve Kurts (1945) yöntemiyle belirlenmiştir. Çalışma alanına ait elde edilen toprak analiz sonuçlarına ait tanımlayıcı istatistikler SPSS 12.0 paket programında yapılmış, havzanın temel coğrafi özellikleri olan eğim, bakı, yükselti ve kabartı haritalarının üretilmesinde ise ArcGIS $10.2 \mathrm{v}$ programı kullanılmıştır.

\section{BULGULAR ve TARTIŞMA}

Araştırma sahası içerisinde çay tarımı yapılan alanlardan alınan 28 toprak örneğinde yapılan bazı tanımsal istatistik özellikleri Çizelge 1 'de ve bazı fiziksel ve kimyasal analiz sonuçları ise sırasıyla Çizelge 2 ve 3 'de verilmiştir. Normal dağılım simetrik bir dağıımdır. Normal dağıımda simetrikliğin bozulma derecesine çarpıklık (skewness) denir. Dağılış sağa uzun kuyruklu ise sağa (pozitif) çarpık, sola uzun kuyruklu ise sola (negatif) çarpık olarak adlandırılır. Normal dağılım eğrisinin sivrilik veya yuvarlaklık derecesine basıklık (kurtosis) denir (Yıldız ve ark. 1998). Çizelge 1 incelendiğinde çarpıklık katsayıları AS, DO, kum, ve silt normal dağılım sergilerken diğer özellikler ise normal dağılımdan uzaktır. Wilding (1985), toprak özelliklerindeki değişimlerin açıklanmasında önemli bir gösterge olarak kabul edilen değişkenlik katsayısını, aldığı değerlere göre düşük (<\%15), orta (\%1535) ve yüksek (>\%35) olarak sınıflandırmaktadır (Mallants et al. 1996). Bu çalışmada pH, EC, Kireç, OM, K, Na, Mg ve DO değişkenlik katsayıları düşük iken; $A S$, silt, kum ve $P$ ise yüksek değişkenlik özellikleri göstermektedir.

Çizelge 1. Toprakların fiziksel ve kimyasal özelliklerinin tanımlayıcı istatistikleri.

\begin{tabular}{|c|c|c|c|c|c|c|c|c|}
\hline Parametreler & Ortalama & $\begin{array}{l}\text { Standart } \\
\text { sapma }\end{array}$ & $\begin{array}{l}\text { Değişkenlik } \\
\text { katsayısı* }\end{array}$ & Varyans & $\begin{array}{l}\text { En düşük } \\
\text { değer }\end{array}$ & $\begin{array}{l}\text { En yüksek } \\
\text { değer }\end{array}$ & Çarpıklık** & Basıklık \\
\hline Kum & 56.89 & 9.34 & 40.94 & 87.30 & 35.37 & 76.31 & 0.13 & 0.00 \\
\hline Kil & 11.50 & 5.14 & 19.29 & 26.47 & 4.12 & 23.41 & 0.69 & -0.01 \\
\hline Silt & 31.60 & 7.97 & 38.56 & 63.55 & 15.34 & 53.90 & 0.47 & 1.19 \\
\hline $\mathrm{pH}$ & 4.34 & 0.94 & 3.99 & 0.89 & 3.38 & 7.37 & 1.69 & 3.02 \\
\hline EC & 0.29 & 0.15 & 0.59 & 0.02 & 0.03 & 0.61 & 0.64 & -0.59 \\
\hline Kireç & 0.15 & 0.28 & 1.49 & 0.07 & 0.10 & 1.59 & 5.29 & 28.00 \\
\hline OM & 5.39 & 2.29 & 10.33 & 5.28 & 1.17 & 11.50 & 0.55 & 0.49 \\
\hline $\mathrm{N}$ & 0.30 & 0.11 & 0.50 & 0.01 & 0.13 & 0.63 & 0.67 & 0.99 \\
\hline$P$ & 48.23 & 35.71 & 123.63 & 1275.77 & 4.55 & 128.18 & 0.79 & -0.45 \\
\hline K & 0.35 & 0.28 & 1.12 & 0.08 & 0.06 & 1.18 & 1.36 & 1.48 \\
\hline $\mathrm{Ca}$ & 4.13 & 6.71 & 24.88 & 45.09 & 0.08 & 24.96 & 2.08 & 3.80 \\
\hline $\mathrm{Mg}$ & 0.87 & 0.90 & 3.04 & 0.82 & 0.05 & 3.09 & 1.36 & 0.82 \\
\hline $\mathrm{Na}$ & 0.19 & 0.28 & 1.06 & 0.07 & 0.00 & 1.06 & 1.82 & 2.72 \\
\hline AS & 70.73 & 8.75 & 36.50 & 76.69 & 55.52 & 92.02 & 0.39 & 0.14 \\
\hline DO & 10.31 & 4.19 & 14.29 & 17.63 & 3.85 & 18.14 & 0.25 & -0.89 \\
\hline
\end{tabular}

*Değişkenlik Katsayısı: <15 = Düşük Değişkenlik, 15-35 = Orta Değişkenlik, >35 = Yüksek Değişkenlik; **Çarpıklık:<|Ғ0,5 |= Normal Dağılım, 0,5- 1,0 = Veri setine karakter dönüşümü uygulanır. ÇK $>1,0 \rightarrow$ Logaritma dönüşümü uygulanır 
Havza içerisinde dağılım gösteren çay tarım topraklarının bazı kimyasal özellikleri bakımından çizelge 2 incelendiğinde, büyük çoğunluğu pH değerleri (17 nolu örnek hariç) hafif asit ile kuvvetli asit arasında değişmektedir. Ülgen ve Yurtsever (1995) tarafından bildirilen sınır değerlerine göre, araştırma alanından alınan toprak örneklerinin analiz sonuçları sınıflandırıldığında; $\mathrm{pH}$ değerleri yüzeyde ve derinde her iki durumda da kuvvetli asit, orta ve hafif asit değerleri arasında değiştiği belirlenmiştir. Birçok araştırmacının belirttiğine göre (Kacar 1984), çay tarımı için optimum pH aralığı 4.5-6.0 arasında değişiklik göstermektedir. Toprakların kuvvetli asit düzeylerine gelmelerinde en önemli etken yağışın ve toprak bünyesinin kum fraksiyonunun yüksek olmasından dolayı bazik katyonların yıkanarak ortamdan uzaklaşmasıdır. Çalışma alanı çay topraklarındaki pH'nın bu değişim aralığıyla ilgili bulgular, daha önce Karadeniz Bölgesinin diğer alanlarında yapılan araştırma bulguları ile büyük ölçüde benzerlik göstermektedir (Müftüoğlu 1990; ve Özyazıcı ve ark. 2010). Ayrıca, Özyazıcı ve ark. (2016) yaptıkları araştırmada Rize ili tarım topraklarının pH'sının 3.14-6.05 arasında değiştiğini, alınan örneklerin \%94.34'ünde pH'nın 4.5' in altında olduğunu saptamışlardır. Toprakların EC değeri 0.121-0.547 $\mathrm{dSm}^{-1}$ arasında değişmekte ve tuzluluk problemleri görülmemektedir. 17 nolu toprak örneği hariç, diğer toprak örneklerinde kireç belirlenmemiş̧ir. Saygın ve ark. (2017) Trabzon'un Of ilçesine ait Çataklı Çayı Havzası doğu yakasındaki çay tarımı yapılan toprakların fiziksel, kimyasal ve verimlilik özelliklerinin, belirlenmesine yönelik farklı yükseklik, yöney ve ana materyale ait aldıkları toprak örneklerinde kireç değerini \%0.01 ile \%1.97 arasında belirlemişlerdir. Kireç içeriğinin genelde çok düşük olması, yüksek yağış nedeniyle profilden karbonatların yıkanmasının yanı sıra toprakların kireçsiz ana materyale sahip olması şeklinde açıklanabilir. Toprakların verimlilik özellikleri üzerine olan etkileri kadar, fiziksel özellikleri üzerine özellikle de agregat oluşumu ve dayanıklılığında organik maddenin önemli rolü bulunmaktadır. Yılmaz ve Alagöz (2005) organik materyallerin etkin bir biçimde kullanımının toprakların agregat oluşumu ve stabilitesini geliştirebileceği üzerine yaptıkları çalışmada, değişik kökene sahip üç adet organik materyalin (soya küspesi, pamuk küspesi ve ahır gübresi) $0-25 \mathrm{~cm}$ derinliğinden alınan toprağa uygulanması ile toprağın agregat oluşumu ve stabilitesi üzerine etkileri araştırılmıştır. Elde ettikleri sonuçlara göre, agregat stabilitesi üzerine etki bakımından soya küspesi ve ahır gübresi uygulamaları istatistiksel olarak önemlilik göstermezken, pamuk küspesi uygulaması 8-4 $\mathrm{mm}$ boyuta sahip agregatların stabilitesinde \%1, 1-0.5 mm boyuta sahip agregatların stabilitesinde ise \%0.1 düzeyinde önemli olmuştur. Organik madde yönünden çalışma alanı topraklarının kapsamları incelendiğinde, organik madde içeriklerinin \%1.17- \%11.50 arasında değişmekte ve ortalama olarak \%5.39 olduğu belirlenmiştir. Charman ve Roper (2007)'e göre yapılan sınıflandırmada, yüzey topraklarının \%1.0' az, $\% 17.85^{\prime}$ inin orta ve $\% 21.42$ 'sinin yüksek ve $\% 59.71$ ise düzeyde organik madde içerdiği belirlenmiştir (Çizelge 1). Özyazııı ve ark. (2016) Rize ili tarım arazilerinden 159 adet alınan toprak örneklerinde Ülgen ve Yurtsever (1995)'e göre yapılan sınıflandırmada iyi ve yüksek seviyede organik madde içeren toprak örneklerinin oranı \%83.02 olarak belirlemişlerdir. Yöre tarım topraklarında organik maddenin yüksek oluşu; yağışın fazla, sıcaklığın ise az olması nedeni ile organizma faaliyetlerinin yavaşlaması, dolayısıyla parçalanma ve ayrışmanın az olmasının neden olduğu organik madde birikimi ile açıklanabileceğini belirtmişlerdir. Topraklarda azot değişkenlik katsayıları düşük olup, en düşük $\% 0.13$ ve en yüksek olarak $\% 0.63$ iken ortalama $\% 0.30$ olarak belirlenmiştir. Bruce ve Rayment (1982) göre toprakların yaklaşık \%28.5'i orta düzeyde iken \%64.28'i yüksek ve çok yüksek düzeydedir. Incelenen topraklarının alınabilir yarayışlı fosfor (P) içerikleri incelendiğinde $4.55 \mathrm{mg} . \mathrm{kg}^{-1}$ ile $1128.18 \mathrm{mg} \cdot \mathrm{kg}^{-1}$ arasında değişmektedir. Hazelton ve Murph (2007)' e göre toprakların \%14.2' sinde fosfor içerikleri düşük olarak belirlenmesine karşın büyük bir çoğunluğunda $\mathrm{P}$ içerikleri yüksek ve çok yüksek olarak belirlenmiştir. Benzer bulgular Özyazıcı ve ark. (2016) ve Müftüoğlu ve ark. (2010) tarafından da elde edilmiştir. Toprakların bazik katyon içerikleri de oldukça düşük olup baskın bazik katyon Ca iyonları olduğu belirlenmiştir. 
Çizelge 2. Yüzey $(0-20 \mathrm{~cm})$ topraklarının bazı kimyasal analiz sonuçları.

\begin{tabular}{|c|c|c|c|c|c|c|c|c|c|c|}
\hline \multirow[t]{2}{*}{ Örnek No } & \multirow[t]{2}{*}{$\mathrm{pH}$} & \multirow[t]{2}{*}{$\mathrm{EC} \mathrm{dSm}^{-1}$} & \multirow[t]{2}{*}{ Kireç \% } & \multirow[t]{2}{*}{ OM \% } & \multirow[t]{2}{*}{$\mathrm{N} \%$} & \multirow[t]{2}{*}{ P mg.kg-1 } & $\mathrm{K}$ & $\mathrm{Ca}$ & $\mathrm{Mg}$ & $\mathrm{Na}$ \\
\hline & & & & & & & \multicolumn{4}{|c|}{$\mathrm{me} / 100 \mathrm{~g}$} \\
\hline 1 & 4.0 & 0.268 & 0.0 & 5.59 & 0.39 & 29.90 & 0.4 & 0.74 & 0.5 & 0.0 \\
\hline 2 & 4.1 & 0.167 & 0.0 & 1.17 & 0.14 & 23.25 & 0.1 & 1.26 & 0.5 & 0.0 \\
\hline 3 & 3.6 & 0.025 & 0.0 & 2.24 & 0.13 & 39.17 & 0.0 & 0.53 & 0.3 & 0.0 \\
\hline 4 & 3.6 & 0.223 & 0.0 & 6.76 & 0.38 & 7.65 & 0.2 & 0.46 & 0.3 & 0.0 \\
\hline 5 & 3.5 & 0.485 & 0.0 & 5.31 & 0.34 & 114.19 & 0.1 & 0.74 & 0.2 & 0.0 \\
\hline 6 & 3.5 & 0.546 & 0.0 & 8.82 & 0.40 & 21.04 & 0.1 & 0.08 & 0.2 & 0.0 \\
\hline 7 & 5.1 & 0.343 & 0.0 & 3.83 & 0.21 & 27.13 & 0.5 & 11.8 & 3.0 & 0.1 \\
\hline 8 & 3.8 & 0.159 & 0.0 & 3.80 & 0.20 & 20.35 & 0.1 & 0.32 & 0.2 & 0.0 \\
\hline 9 & 4.6 & 0.187 & 0.0 & 5.38 & 0.20 & 7.20 & 0.2 & 0.60 & 0.2 & 0.3 \\
\hline 10 & 4.2 & 0.121 & 0.0 & 3.54 & 0.19 & 69.21 & 0.2 & 1.62 & 0.6 & 0.0 \\
\hline 11 & 5.6 & 0.236 & 0.0 & 5.42 & 0.28 & 32.80 & 0.6 & 9.01 & 2.0 & 0.0 \\
\hline 12 & 3.3 & 0.371 & 0.0 & 7.83 & 0.47 & 53.01 & 0.1 & 0.21 & 0.1 & 0.0 \\
\hline 13 & 3.5 & 0.324 & 0.0 & 5.49 & 0.32 & 101.18 & 0.3 & 0.32 & 0.2 & 0.0 \\
\hline 14 & 4.2 & 0.547 & 0.0 & 5.46 & 0.35 & 25.96 & 0.1 & 22.3 & 1.2 & 0.0 \\
\hline 15 & 3.6 & 0.456 & 0.0 & 8.48 & 0.33 & 21.94 & 0.4 & 0.12 & 0.0 & 0.0 \\
\hline 16 & 4.9 & 0.208 & 0.0 & 7.20 & 0.45 & 73.72 & 0.3 & 3.48 & 1.0 & 0.4 \\
\hline 17 & 7.3 & 0.546 & 1.6 & 5.46 & 0.36 & 93.25 & 0.5 & 24.9 & 2.1 & 0.3 \\
\hline 18 & 3.7 & 0.256 & 0.0 & 5.70 & 0.31 & 48.97 & 0.2 & 0.10 & 0.2 & 0.1 \\
\hline 19 & 4.3 & 0.180 & 0.0 & 3.30 & 0.16 & 4.55 & 0.1 & 0.10 & 0.2 & 0.2 \\
\hline 20 & 3.8 & 0.211 & 0.0 & 2.88 & 0.23 & 128.18 & 0.7 & 0.55 & 0.3 & 0.0 \\
\hline 21 & 4.8 & 0.319 & 0.0 & 8.17 & 0.35 & 17.93 & 0.1 & 0.61 & 0.2 & 0.8 \\
\hline 22 & 3.5 & 0.225 & 0.0 & 4.16 & 0.29 & 48.70 & 0.2 & 1.86 & 0.7 & 0.0 \\
\hline 23 & 6.4 & 0.455 & 0.0 & 5.56 & 0.34 & 43.22 & 0.6 & 13.4 & 2.3 & 1.0 \\
\hline 24 & 4.5 & 0.169 & 0.0 & 2.82 & 0.17 & 29.17 & 0.6 & 5.31 & 0.6 & 0.2 \\
\hline 25 & 5.3 & 0.162 & 0.0 & 2.90 & 0.16 & 8.96 & 0.1 & 10.1 & 3.0 & 0.0 \\
\hline 26 & 4.3 & 0.210 & 0.0 & 11.50 & 0.63 & 108.24 & 1.1 & 3.96 & 1.4 & 0.6 \\
\hline 27 & 3.6 & 0.614 & 0.0 & 7.30 & 0.34 & 83.62 & 0.9 & 0.88 & 1.4 & 0.5 \\
\hline 28 & 3.9 & 0.136 & 0.0 & 4.88 & 0.29 & 67.97 & 0.0 & 0.21 & 0.1 & 0.0 \\
\hline
\end{tabular}

Toprağın kum, kil ve silt gibi parçacıkların oranından oluşan toprak bünyesi, toprağın verimlilik düzeyinin yanı sıra erozyon duyarlılık parametreler üzerine etki yapan önemli fiziksel özelliklerindendir. Çalışma alanı içerisinde yer alan çay tarımı yapılan toprakların bünye özellikleri; 0$20 \mathrm{~cm}$ derinlikte kum, kil ve silt içerikleri sırasıyla \%35.7176.31, \%4.12-23.41 ve \%15.34-53.93 arasında değişmektedir. Toprak örnekleri tın (L), kumlu tın (SL), siltli tın (SiL) tın olmak üzere 3 farklı bünye sınıfında tespit edilmiş olup, toprakların büyük çoğunluğunu kaba (SL) bünyeye sahip topraklar oluşturmaktadır (Çizelge 3).

Toprakların agregat dağılımları ve stabilite ölçümleri toprakların bir kalite göstergesi olarak kabul edilmesinin (Six ve ark. 2000) yanı sıra, agregat stabilitesi ölçümleri toprak agregatlarının bozulmaya neden olan çevresel etmenlere karşı direncinin belirlenmesinde önemli bir gösterge olarak dikkate alınmaktadır (Hillel 1982). Bu nedenle, toprak ve su korumaya yönelik planlamalarda toprağın strüktürel devamlılığının değiştirilmesine karşı toprağın göstereceği direncin ve erozyona uğrama eğiliminin bilinmesine gerek duyulmaktadır (Sönmez ve Özdemir 1988). Havzadan alınan örneklerde yapılan analizler sonucu bulunan agregat stabilitesi değerlerinin \%55.52 ile \%92.02 arasında olduğu belirlenmiştir. Havzanın ortalama olarak agregat stabilitesi değeri ise \%70.74 olarak bulunmuştur. Ayrıca, çalışma alanının toprak örneklerine ait agregat stabilitesi değerleri incelendiğinde örnek sayısının yarısından fazlasının \%70'in üzerinde stabil agregata sahip olduğu belirlenmiştir.

Dispersiyon oranı, topraktaki doğal agregatların su ile temas ettiğinde çözülme (dispersleşme) derecesini gösteren önemli bir göstergedir. Eğer topraktaki en küçük boyuta sahip agregatlar dahi suya dayanıklı ise toprak erozyona dirençli olmaktadır. Dispersiyon oranı \%15'ten küçük olan topraklar erozyona karşı dayanıklıdırlar. Dispersiyon oranı $\% 15$ 'ten büyük olan toprakların ise erozyona karşı dayanıksız oldukları belirtilmektedir (Bryan 
1968). Yapılan analizler sonucu dispersiyon oranı değerlerinin \%3.85 ile \%18.14 arasında olduğu belirlenmiştir. Havzanın ortalama dispersiyon oranı ise \%10.32 olarak bulunmuştur. Buna karşılık, Erol ve ark. (2009) tarafından Antalya havzasının Isparta sınırları içerisinde yer alan Darıderesi havzasında, yaptıkları çalışmada elde ettikleri sonuçlarda dispersiyon oranı değerlerinin orman, tarım ve mera topraklarında \%32.87, \%38.53 ve \%46.96 arasında değişmekte olduğunu ve tüm arazi kullanım türlerine ait toprakların DO yönünden erozyona karşı dayanıksız olduklarını belirlemişlerdir.

Çizelge 3. Yüzey $(0-20 \mathrm{~cm})$ topraklarının bazı fiziksel analiz sonuçları.

\begin{tabular}{|c|c|c|c|c|c|c|}
\hline Örnek No & Kum & Kil & Silt & Bünye Sınıfı & AS & DO \\
\hline 1 & 65.19 & 7.05 & 27.76 & Kumlu tın (SL) & 87.12 & 5.87 \\
\hline 2 & 53.41 & 13.34 & 33.25 & Kumlu tın (SL) & 55.52 & 12.88 \\
\hline 3 & 53.52 & 7.17 & 39.32 & Kumlu tın (SL) & 59.73 & 16.30 \\
\hline 4 & 61.27 & 19.41 & 19.32 & Kumlu tın (SL) & 70.59 & 14.30 \\
\hline 5 & 43.12 & 23.41 & 33.46 & $\operatorname{Tın}(L)$ & 71.47 & 9.61 \\
\hline 6 & 55.24 & 9.25 & 35.51 & Kumlu tın (SL) & 71.55 & 10.22 \\
\hline 7 & 49.53 & 15.14 & 35.33 & $\operatorname{Tın}(\mathrm{L})$ & 65.34 & 10.12 \\
\hline 8 & 48.92 & 17.46 & 33.62 & $\operatorname{Tın}(L)$ & 65.07 & 13.63 \\
\hline 9 & 55.84 & 12.82 & 31.34 & Kumlu tın (SL) & 80.01 & 4.94 \\
\hline 10 & 53.35 & 12.95 & 33.7 & Kumlu tın (SL) & 73.04 & 8.81 \\
\hline 11 & 64.44 & 11.01 & 24.54 & Kumlu tın (SL) & 71.01 & 8.14 \\
\hline 12 & 61.88 & 11.22 & 26.9 & Kumlu tın (SL) & 79.34 & 17.16 \\
\hline 13 & 47.61 & 9.24 & 43.15 & $\operatorname{Tın}(\mathrm{L})$ & 73.04 & 8.25 \\
\hline 14 & 66.18 & 4.89 & 28.93 & Kumlu tın (SL) & 66.82 & 9.51 \\
\hline 15 & 76.31 & 8.35 & 15.34 & Kumlu tın (SL) & 80.38 & 4.07 \\
\hline 16 & 51.29 & 12.75 & 35.96 & $\operatorname{Tın}(L)$ & 71.00 & 6.38 \\
\hline 17 & 35.37 & 10.73 & 53.9 & Siltli tın (SiL) & 62.21 & 8.24 \\
\hline 18 & 52.08 & 14.46 & 33.46 & Kumlu tın (SL) & 77.01 & 6.34 \\
\hline 19 & 66.66 & 7.75 & 25.59 & Kumlu tın (SL) & 57.83 & 12.00 \\
\hline 20 & 54.35 & 22.57 & 23.08 & Kumlu killi tın (SCL) & 63.98 & 11.27 \\
\hline 21 & 71.13 & 5.69 & 23.17 & Kumlu tın (SL) & 92.02 & 4.59 \\
\hline 22 & 51.68 & 5.74 & 42.58 & Kumlu tın (SL) & 80.41 & 16.93 \\
\hline 23 & 56.33 & 14.96 & 28.7 & Kumlu tın (SL) & 63.20 & 12.69 \\
\hline 24 & 54.11 & 10.69 & 35.2 & Kumlu tın (SL) & 70.80 & 15.72 \\
\hline 25 & 48.41 & 16.4 & 35.2 & $\operatorname{Tın}(\mathrm{L})$ & 71.85 & 18.14 \\
\hline 26 & 55.61 & 7.97 & 36.42 & Kumlu tın (SL) & 57.77 & 11.02 \\
\hline 27 & 72.62 & 4.12 & 23.26 & Kumlu tın (SL) & 68.95 & 7.96 \\
\hline 28 & 67.48 & 5.7 & 26.82 & Kumlu tın (SL) & 73.55 & 3.85 \\
\hline
\end{tabular}

Erozyon; iklim karakteristikleri, topoğrafya, toprak özellikleri, bitki örtüsü ve arazi kullanımı gibi faktörler tarafından kontrol edilir ve bundan dolayıdır ki bu faktörlerin birbirleri ile olan ilişkisi ve etki derecesinin belirlenmesi gerekir. Bu amaçla günümüze kadar laboratuvar ve arazi koşullarında birçok çalışma yapılmıştır. Yapılan çalışmalarda değişkenler kaydedilerek, en uygun ilişkiler korelasyon ve regresyon analizleri içeren istatistiki metotlarla araştırılmıştır (Morgan 1991). Bu araştırmalar sonucu erozyonun duyarlılıklarının belirlenmesinde ve toprak kayıplarının tahmininde kullanılacak değerlerin, çok geniş alanlarda genel yaklaşımlar yerine, farklı ekolojik özelliklere sahip lokal alanlarda yapılan çalışmalardan sağlanması gerekliliği ortaya çıkmıştır. Toprağın fiziksel ve kimyasal özellikleri ile aşınabilirlik göstergeleri olan Agregat Stabilitesi ve Dispersiyon Oranı arasındaki korelasyon katsayıları ve önem düzeyleri Çizelge 4'te verilmiştir. Yapılan korelasyon testine göre, agregat stabilitesi ile dispersiyon oranı arasında $-0.38^{\prime}$ lik negatif öneme sahip bir ilişki çıkmıştır. Yani dispersiyon oranı arttıkça agragat stabilitesi değerinin düştüğü görülmektedir. Agregat stabilitesi ile kil arasında pozitif yönde bir ilişki olmasına rağmen, silt ve kum miktarı arasında negatif yönde bir ilişki çıkmıştır. Agregat stabilitesi, dispersiyon oranı ve diğer toprak özellikleri ilişkisinde en yüksek pozitif korelasyon organik madde ile azot $\left(0.89^{* *}\right)$ görülürken, en yüksek negatif korelasyon kum ile silt $\left(-0.83^{* *}\right)$ arasında belirlenmiştir. Yakupoğlu ve ark (2015), agregat stabilitesi ile bazı toprak özelliklerinin arasındaki ikili 
ilişkileri inceleyebilmek amacıyla toplam veri kümesi (bir yıllık veriler) kullanılarak bir korelasyon analizi yapmışlardır. Söz konusu tablodan da anlaşılacağı üzere agregat stabilitesi değişkeninin organik madde, tarla kapasitesi, solma noktası, kil $(\mathrm{P}<0.01)$ ve $\mathrm{CaCO}_{3}(\mathrm{P}<0.05)$ ile önemli pozitif, tuz ile önemli negatif $(P<0.01)$ ilişkiler verdiğini belirlemiştir. Ayrıca diğer önemli bir durum da dispersiyon oranı ile organik madde arasında yine negatif yönde önemli bir ilişki belirlenmiştir. Yine, korelasyon tablosuna bakıldığında yüksek organik maddenin varlığı ile $\mathrm{N}$ içeriği arasında doğrusal ve 0.05 seviyesinde önemli bir ilişki çıkmıştır.

Çizelge 4. Toprağın fiziksel ve kimyasal özellikleri arasındaki korelasyon ilişkisi.

\begin{tabular}{|c|c|c|c|c|c|c|c|c|c|c|c|c|c|c|c|}
\hline Parametreler & AS & DO & Kum & Kil & Silt & $\mathrm{pH}$ & $\mathrm{EC}$ & Kireç & OM & $\mathrm{P}$ & $\mathrm{K}$ & $\mathrm{Ca}$ & $\mathrm{Mg}$ & $\mathrm{Na}$ & $\mathrm{TN}$ \\
\hline AS & 1.00 & $-0.38 *$ & -0.21 & $0.35^{*}$ & -0.27 & -0.22 & 0.09 & -0.19 & 0.32 & -0.19 & -0.23 & -0.30 & -0.30 & -0.02 & 0.2 \\
\hline DO & & 1.00 & -0.33 & 0.24 & 0.23 & -0.08 & -0.26 & -0.10 & $-0.38 *$ & -0.15 & -0.09 & 0.06 & 0.19 & -0.19 & -0.25 \\
\hline Kum & & & 1.00 & $-0.52 * *$ & $-0.83 * *$ & -0.31 & 0.11 & $-0.45^{*}$ & 0.34 & $-0.35 *$ & 0.08 & -0.29 & -0.27 & 0.14 & 0.14 \\
\hline Kil & & & & 1.00 & -0.03 & 0.07 & -0.13 & -0.03 & -0.28 & 0.18 & -0.07 & -0.05 & 0.07 & -0.18 & -0.19 \\
\hline Silt & & & & & 1.00 & 0.32 & -0.04 & $0.55^{* *}$ & -0.21 & 0.29 & -0.05 & 0.37 & 0.27 & -0.04 & -0.05 \\
\hline $\mathrm{pH}$ & & & & & & 1.00 & 0.14 & $0.63 * *$ & -0.07 & -0.04 & 0.27 & $0.76^{* *}$ & $0.73 * *$ & $0.48^{* *}$ & -0.03 \\
\hline EC & & & & & & & 1.00 & 0.32 & $0.48 * *$ & 0.19 & 0.22 & 0.41 & 0.19 & 0.25 & $0.45^{*}$ \\
\hline Kireç & & & & & & & & 1.00 & 0.01 & 0.25 & 0.10 & $0.61^{* *}$ & 0.28 & 0.11 & 0.1 \\
\hline OM & & & & & & & & & 1.00 & 0.17 & 0.34 & -0.07 & -0.08 & $0.43^{*}$ & $0.89 * *$ \\
\hline $\mathrm{P}$ & & & & & & & & & & 1.00 & $0.46^{*}$ & 0.01 & -0.02 & 0.11 & $0.38^{*}$ \\
\hline K & & & & & & & & & & & 1.00 & 0.18 & $0.40^{*}$ & $0.49 * *$ & $0.38 *$ \\
\hline $\mathrm{Ca}$ & & & & & & & & & & & & 1.00 & $0.73 * *$ & 0.18 & 0.06 \\
\hline $\mathrm{Mg}$ & & & & & & & & & & & & & 1.00 & 0.28 & -0.02 \\
\hline $\mathrm{Na}$ & & & & & & & & & & & & & & 1.00 & $0.36^{*}$ \\
\hline TN & & & & & & & & & & & & & & & 1.00 \\
\hline
\end{tabular}

\section{SONUÇ}

Bu çalışmada, Rize il sınırları içerisinde yer alan bir mikro havzada çay tarımı yapılan bahçelerden alınan toprak örneklerine ait bazı fiziksel ve kimyasal özelliklerin tespit edilmesi yanı sıra erozyon duyarlılık durumlarının belirlenmesi amacıyla agregat stabilite ve dispersiyon oranlarının ortaya çıkarılmasına yönelik bir araştırma gerçekleştirilmiştir. Elde edilen sonuçların daha önce yapılan birçok benzer çalışmanın sonuçlarıyla da uyumluluk gösterdiği belirlenmiştir. Örneklenen toprakların büyük bir çoğunluğu kaba bünyeli, kireç içermeyen, asit reaksiyonlu ve organik maddece zengin topraklardır. Toprakların organik madde içeriklerinin yüksek olması özellikle agregat stabilite değerleri ile dispersiyon oranlarını olumlu yönde etkilediği düşünülmektedir ki toprak örneklerinin hemen hemen hepsi \%50'nin üzerinde agregat stabilite değerine ve beş örnek haricinde büyük çoğunluğunda $\% 15$ den düşük dispersiyon oranı değerleri belirlenmiştir. \%15 den büyük olan 3, 12, 22, 24 ve 25 nolu örneklerin dispersiyon oranları ise $\% 15$ değerine çok yakındırlar. Zaman içerisinde bu örneklerin de dispersiyon oranları azalabilir. $\mathrm{Bu}$ nedenle toprakların organik madde düzeylerini koruyucu tedbirlerin alınmasının yanı sıra

verimliliklerinde artışın sağlanabilmesi amacıyla çok kuvvetli asit reaksiyonlu alanlarda pH düzeylerini arttırıcı önlemler (bazik katyon içerikli gübre kullanımı, kireçleme vb.) alınmalıdır. Ayrıca, toprak örneklerinin alındığı alanların eğimi dik ve kapalılık oranları yüzde yüze yakın olup çay bitkisi ile kaplıdır. Bu alanların bitki örtüsündeki tahribat veya yanlış tarımsal uygulamalar, toprakların erozyona karşı duyarlııklarını arttıracağından erozyon riski ile karşı karşıya kalınacağı unutulmamalıdır.

\section{KAYNAKLAR}

Anonim (2013) Erozyonla Mücadele Eylem Planı 2013-2017. Orman ve Su İşleri Bakanlığı, Ankara

Anonim (2018a) Rize'nin Coğrafi Özellikleri.

https://www.sohbetche.net/rizenin-cografi-ozellikleri.html. E.T:24.04.2018.

Anonim (2018b) Rize Ilinin İklimi.

http://www.rizekulturturizm.gov.tr/TR,55289/iklim.html. E.T:24.04.2018.

Anonim (2018c). Karadeniz Teknik Üniversitesi. Havza Amenajmanı Anabilim Dalı Ders Notları.

http://www.ktu.edu.tr/dosyalar/havzaamenajmani 42ce4.pdf. E.T:24.04.2018.

Aşkın T, Türkmen F, Tarakçıoğlu C (2016) Ordu ili merkez ilçe topraklarında erozyon riskinin jeoistatistiksel tekniklerle değerlendirilmesi. Toprak Bilimi ve Bitki Besleme Dergisi 4(2);69-7 
Bouyoucous GJ (1951) A Recalibration of the Hydrometer for Making Mechanical Analysis of Soil Agronomy Journal, 43: 434-438.

Bremner JM (1965) Inorganic Forms of Nitrogen. Methods of Soil Analysis. Black, C.A. American Soc. Of Agron. Inc. Publ. Madison Wis., USA, 1197-1287.

Bryan RB (1968) The development, use and efficiency of indices of soij erodibility. Geoderma, 2: 2-25.

Bray RH, Kurtz LT (1945) Determination of total, organic, and available forms of phosphorus in soils. Soil Sci., 59: 39-45.

Bruce RC, Rayment GE (1982) Analytical methods and interpretations used by the Agriculture Chemistry Branch for Soil and Land Use Surveys. Queenlands Department of Primary Industries. Bylletin QBB, Indooroopilly, Queenland.

Baumgartl T (2002). Atterberg Limits. Encyclopedia of Soil Science, Marcel Dekker Inc. pp: 89-93

Charman PEV, Roper MM (2007) Soil organic matter. In "Soil-theri properties and management" 3rd edn (Eds P.E.V Charman and B.W. Murphy)Oxforf University Press, 276-285.

Eraslan S, İmamoğlu A, Coşkun A, Saygın F, Dengiz O (2016) İnebolu Havzası topraklarının erozyon duyarlııklarını belirlenmesinde agregat ve strüktür stabilite durumları, arazi örtüsü ile olan ilişkileri. Uluslararası Coğrafya Sempozyumu, 13-14 Ekim, TÜCAUM, 779-794. Ankara.

Erol A, Babalık AA, Sönmez K, Serin N (2009) Isparta-Darıderesi Havzası Topraklarında Erozyona Duyarlıı̆ı̆n Arazi Kullanım Şekillerine Bağlı Değişimi Süleyman Demirel Üniversitesi Orman Fakültesi Dergisi. A;2, 21.36.

Güven H (1993) Doğu Karedeniz Bölgesi'nin 1/100.000 ölçekli harita ve jeoloji raporu, Maden Tetkik ve Arama Genel Müdürlügü, Ankara.

Hazelton P, Murphy B (2007) Interpreting Soil Test Results. What do the Numbers Mean. NSW Department of Natural Resources, p 152.

Hillel D (1982) Introduction to Soil Physics. 2 nd ed. Academic Press, San Diego, CA.

Kacar B (1994) Bitki ve Toprağın Kimyasal Analizleri III. (Toprak Analizleri). Ankara Üniversitesi Ziraat Fakültesi Eğitim Araştırma ve Geliştirme Fonu Yayınları, No. 3, Ankara.

Kanar E, Dengiz O (2015) Madendere Havzası Topraklarında Arazi Kullanım/Arazi Örtüsü ile Bazı Erozyon Duyarlıık İndeksleri Arasındaki İlişkinin Belirlenmesi. Türkiye Tarımsal Araştırmalar Dergisi, 2(1): 15-27.

Kemper WD, Rosenau RC (1986) Aggregate Stability and Size Distribution. Methods of Soil Analysis. Part I. Pyhsical and Mineralogical Methods. $2^{\text {nd }}$ Edition. Agronomy No:9. 425-442, 1188 p, Madison, Wisconsin, USA.
Lal R (1988) Soil Erosion Research Methods. Soil and Water Conservation Society, Lucie Press, Florida.

Mallants D, Mohanty BP, Jacques D, Feyen J (1996) Spatial variability of hydraulic properties in a multi-layered soil profile. Soil Science, 161(3), 167-181.

Newhall F (1972) Calculation of soil moisture rejime from climatic records. Inpublished. Soil Conservation Service, USDA. Rev. 4. Washington, D.C

Olsen SR, Sommers LE (1982) Phosphorus Methods of Soil Analysis. Part II. Chemical and Microbiological properties. (Page et al.) p.403-430. ASA, SSSA, Madison, WI.

Özdemir N, Öztürk E, Kop Durmuş ÖT, Ekberli I (2015) Effects of organic and inorganic amendments on soil erodibility. Eurasian J Soil Sci, 4 (4); $266-271$.

Richards LA (1954) Diagnosis and Improvement of Saline and Alkaline Soils. U.S. Dept. Agr. Handbook, 60, 109. Riverside.

Sağlam MT (1997) Toprak ve suyun kimyasal analiz yöntemleri. Trakya Üni. Ziraat Fak. Yayın No: 189, Ders Kitabı No: 5, 2. Baskı, Tekirdağ.

Six J, Elliott ET and Paustian K (2000) Soil Structure and Soil Organic Matter: A Normalized Stability Index and the Effect of Mineralogy. Soil Science Society of America Journal, 64: 1042-1049.

Soil Survey Staff (1992) Procedures for collecting soil samples and methods of analysis for soil survey. Soil Surv. Invest. Rep. I. U.S. Gov. Print. Office, Washington D.C. USA.

Van Wambeke AR (2000) The Newhall Simulation Model for estimating soil moisture and temperature regimes. Department of Crop and Soil Sciences. Cornell University, Ithaca, NY.

Sönmez K, Özdemir N (1988) Iğdır Ovası Yüzey Topraklarının Bazı Fiziksel ve Kimyasal Özellikleri İle Strüktürel Dayanıklıık Ölçütleri Arasındaki ïlişkiler, Atatürk Üniversitesi Ziraat Fakültesi Ziraat Dergisi, Cilt: 19, Sayı: 1-4, 155-163.

Wilding LP (1985) Spatial variability: It's documentation, accommodation and implication to soil surveys. In: Soil Spatial Variability. (Eds: Nielsen, D.R. and J. Bouma) Pudoc, Wageningen, The Netherlands, p. 166-194.

Yakupoğlu T, Şişman AÖ, Gündoğan R (2015) Toprakların agregat stabilitesi değerlerinin yapay sinir ağları ile tahminlenmesi. Türkiye Tarımsal Araştırmalar Dergisi, 2:89-9.

Yıldız N, Akbulut Ö, Bircan H (1998) İstatistiğe giriş. Erzurum: Şafak Yayınevi.

Yılmaz E, Alagöz Z (2005) Organik Materyal Uygulamasının Toprağın Agregat Oluşum ve Stabilitesi Üzerine Etkileri. Akdeniz Üniversitesi Ziraat Fakültesi Dergisi, 18(1), 131-138. 